\title{
Pesticides use, practice and its effect on honeybee in Ethiopia: a review
}

\author{
Zekiros Fikadu $^{1}$
}

Received: 13 September 2019 / Accepted: 27 January 2020 / Published online: 1 February 2020

(C) The Author(s) 2020

\begin{abstract}
Honeybees play an essential economic role in the pollination of crops. Farmers were buying, storing, and use pesticides on cultivated plants with no or little consideration of the effect on honeybees. In Ethiopia, pesticide poisoning of honeybees has increased from time to time, and beekeepers also lose their colonies due to unwise use and improper practice of pesticides. Ethiopia has developed a legal framework on pesticide registration, distribution, and use. But regulations are not strictly implemented by the farmers, and it needs enforcement. Farmers use pesticides on crops with no or little consideration of their effect on honeybees, also the use of pesticides is harmful to pollination service, behavior, communication, forage resource, poisoning, and contaminated hive products. The Effective communication between beekeepers and crop growers is important because spraying pesticides is required to minimize the impact of pesticides on honeybees. The present review should focus on the effects of pesticide use and the means of reducing its impact on honeybee colonies.
\end{abstract}

Keywords Effect $\cdot$ Honeybee $\cdot$ Pesticide $\cdot$ Pollination $\cdot$ Use

\section{Introduction}

Pesticide refers to a wide range of compounds including insecticides, herbicides, fungicides, rodenticides, molluscicides and plant growth regulators. Pesticides use as crop pesticides in the agricultural sector were introduced in Ethiopia with the development of commercial farms in the beginning 1960s (EPA 2004; Mengistie 2016a, 2016b). Following the introduction, use of chemical pesticides was applied as integrated package projects including the Chilalo Agricultural Development Unit (CADU), Wolaita Agricultural Development Unit (WADU), Minimum Package Project (MPP) under the Extension and Project Implementation Department (EPID) by the Ministry of Agriculture (Tadesse 2016). Ethiopia imports diverse types of pesticide with the amount expected bout 3346.32 metric tons annually (Gizachew 2011).

Electronic supplementary material The online version of this article (https://doi.org/10.1007/s42690-020-00114-x) contains supplementary material, which is available to authorized users.

Zekiros Fikadu

zekat2007@yahoo.com

1 Department of Animal Science, Shire Campus, Aksum University, Shire, Ethiopia
Agrochemical poisoning, lack of equipment, pest and predators are found to be the top three challenges for the beekeeping industry and about three-quarters of beekeepers lost their colonies due to sprayed agrochemicals (Mengistu and Beyene 2014). Improper use of pesticides in crop production is a source of socio-economic conflict among farmers. In Ethiopia, the poisoning of honeybees by application of pesticides has increased from time to time, and some beekeepers were also lost all their colonies due to agrochemical application (Kerealem et al. 2009). Insecticides and herbicides had been reported as significant causes of the death of the colonies and absconding (Melaku et al. 2008; Desalegn 2014; Melisie et al. 2016; Krystyna et al. 2017; Guesh et al. 2018). Improper use of insecticide leads to the honeybee's death (Chauzat et al. 2006: MOWR 2007) and the decline of honeybee products and crop yield are among the significant constraints of the beekeeping sector (Melisie et al. 2015).

The Ministry of Agriculture (MoA) at the federal level and agricultural bureau at regional states are agencies responsible for regulating, implementing, and monitoring pesticide policies, pesticide registration, importation, distribution, and use. Because of policy framework plays a vital role in the implementation of any regulation (Gysen et al. 2006). In order to govern pesticide use by farmers, the Ethiopian government has formulated new pesticide legislation which is Pesticide Registration and Control Proclamation No. 674/2010. 
Extensive use of pesticides on crop results in decrease the pollination service of honeybees (Chauzat et al. 2006). Smallholder farmers use pesticides as technology inputs, to produce subsistence and commercial crops of different varieties and honeybees' have an immense contribution to agricultural crop pollination (Klein et al. 2007; Winfree et al. 2007; Rader et al. 2009). However, the impacts of pesticides on honeybee production are likely to be aggravated by the limited knowledge among users on toxicological and chemical properties of these substances and the fact that labels on pesticide containers were in a language that cannot be understood. Therefore, the objective of this paper is to review pesticide use, practice, their effect on honeybees', the effect of honeybees' pollination service on agriculture crops and farmer's knowledge, attitude and perceptions regarding the impact of pesticides use on honeybees' in Ethiopia.

\section{Impact of pesticides on honeybee colonies}

Globally concerning the amount applied and the extent of use of pesticides are the second group of human-made chemicals after the fertilizers (AAAS 2013). It results in declining the population of honeybee and other pollinators throughout the world (Lebuhn et al. 2013), and toxic to honeybees even at very low doses (Johnson et al. 2010; Krupke et al. 2012; Simon-Delso et al. 2014; Williamson et al. 2014; Chakrabarti et al. 2015). Improper pesticides use also harms the natural environments, harmful and beneficial organisms were kill leading, climate change, pest resistance, and biodegradation (Ajayi 2005). The population dynamics of the honeybee has been affected and declined by different factors; the use of organo-synthetic pesticides is considered to be among the critical elements (Van der Sluijs et al. 2013).

Agrochemical poisoning is the primary challenge for the beekeeping sector, and on average farmers lost more than two colonies per year in West Gojjam Zone, Ethiopia (Mengistu and Beyene 2014). This indicates that the use of different chemicals to agricultural crops is high affects the economy of beekeepers. Honeybees are expos to different types of artificial chemical substances. Due to the deficiency in the number of genes encoding detoxification enzymes, honeybees are extremely sensitive than other insects to pesticides (Claudianos et al. 2006) and the extent of colonies damaged in confirmed honeybee poisoning occurrences varied between 10 and $90 \%$ (Pistorius et al. 2009). This is because the exposure is not uniform for honeybees and the extent of particular effects is varied.

In line with the beginning of agriculture modernization, honey bees, and beekeepers are suffering from the unnecessary usage of pesticides every year in the agriculture sector (Maini et al. 2010). Use of pesticides for crop pests, weeds, tsetse fly, mosquitoes and household pests control brings in to focus the real possibility of damaging the delicate equilibrium in the colony, kill the honeybees and their food source (Kerealem et al. 2009; vanEngelsdorp and Meixner 2010; Allsopp et al. 2014; Desalegn 2014; Mengistu and Beyene 2014; Melisie et al. 2016; Askale et al. 2017), decrease hive production (Kerealem et al. 2009; Erik 2013; Mengistu and Beyene 2014; Melisie et al. 2016; Guesh et al. 2018), contaminated pollen (Pistorius et al. 2015) and it also affects the cognitive, behavior, and physiological functions of honeybees (Desneux et al. 2007; Belzunces et al. 2012; Eiri and Nieh 2012). In addition to the poisoning; pesticides use ranking the first among the factors constraining beekeeping in Adami Tullu district Ethiopia (Melisie et al. 2016). Both honeybees and beekeepers are suffered more prominently due to practices used in agricultural development (Porrini et al. 2003; Maini et al. 2010; Mullin et al. 2010). According to Mengistu and Beyene (2014), it is reported that massive deaths of bees at the hive entrance $(75.5 \%)$ and dead broods (14.5\%) were among the significant signs noticed through pesticides sprayed on different crops. Another report also indicates that if honeybees are poisoned by pesticides they display disorientation, aggressiveness, and incapability to enter the hive (Bortolotti et al. 2009).

Through the application of pesticide death, absconding and dwindling of honeybee colonies was occurring and subsequent financial loss was estimated to a total of about 819,291.4 US\$ at selected districts of Amhara Region, Ethiopia (Desalegn 2014). Scientific study also documented that; the use of different pesticides could lead to a significant reduction of foraging activity (Gill et al. 2012; Henry et al. 2012; Schneider et al. 2012; Feltham et al. 2014), brood production (Alburaki et al. 2017), and orientation, dance communication, and return flight of honeybees (Fischer et al. 2014; Williamson et al. 2014). Even also pesticide, more specifically, the neonicotinoids have a capacity to disease resistance capacity of honeybees (Di Prisco et al. 2013; Brandt et al. 2016). In this case, it is possible to review that, use of pesticides has a potential to reducing the honeybee population, affects their nectar and pollen collection behavior and flight intensity as a result production and productivity received from honeybees is decrease.

\section{Pesticides hazard and honeybee pollinators}

One-third of the total human food supply depended on animals and insects, including honeybees pollination (Klein et al. 2007; Said et al. 2015; Roubik et al. 2018). Farmers use different external inputs, including pesticides, to grow subsistence and commercial crops of different varieties for agricultural crop maximization. Honeybees are economically essential insect pollinators in all over the world (Amssalu et al. 2004; Allsopp et al. 2008; Le Conte and Navajas 2008; Muli et al. 2014). Production of agriculture crops is increasing up to 
50 through pollination processes by the honeybees (Klein et al. 2007). In Ethiopia, the economic contribution of biological pollination services in agriculture crops is estimated at about $\$ 815.2$ million dollars (Alebachew 2018).

The resent agricultural growth has led to increased pesticide use resulting in a significant reduction of honey bee population or death, (Klein et al. 2007; Tadesse and Asferachew 2008; Mullin et al. 2010; Potts et al. 2010; Henry et al. 2012; Whitehorn et al. 2012; Nakasu et al. 2014) and pollination service of honeybees (Chauzat et al. 2006; Stanley et al. 2015). A vital crop pollinator particularly honeybees contact these agrochemicals during their trips by flying through contaminated dust clouds, visiting treated plants during collecting nectar and pollen which contains the pesticide. The decline of beneficial insects includes honeybees is a side effect of the practice of protecting crops against undesirable insects through pesticide use. Therefore, the unwise use of pesticides on agricultural crops do not only affects the honeybee directly through killing to them and indirectly reducing their food resource, but it also affects the production of crops through declining the pollination efficiency of honeybees.

\section{Pesticides residues in honeybee products}

Hive products, mainly honey, may be contaminated from the environment, beekeeping practice, and pesticides. Pesticide residues in honey can happen when bees in search nectar and pollen, visit crops that have been treated with various agrochemicals for different reasons (Bogdanov et al. 2007). European Union set regulation 396/2005 EC limit at $10 \mu \mathrm{g}$ per $\mathrm{kg}$ for substances for which no MRL had been established and since September 2008 also the European Commission has set new MRLs, which mostly is between 10 and $50 \mathrm{ng}$ per $\mathrm{g}$ in honey (Blasco et al. 2011).

A scientific report indicates that $44.4 \%$ of the samples contained no detectable residues of the target pesticides (Eissa et al. 2014) and in another case the honey samples collected from Walmara District of Oromia Special Zone, Ethiopia was free of the organochlorine (there is no significant pesticide) residues and the honey in the study area is safe for consumption (Kebebe 2019). In this case even though, the fact no pesticides were detected or not exceeded the admitted level but, it does not necessarily mean that farmers are not using pesticides. Because some time honeybees can make biological transformation/detoxification of toxic substances and extract through their feces to sustain their life.

Different scientific documents reported that pesticide residues(contamination) in honey, wax, bee brood, pollen, and bees in several countries (Chauzat et al. 2006; Martel et al. 2007; Frazier et al. 2008; Mullin et al. 2010; Wiest et al. 2011; Ostiguy and Eitzer 2014; Porrini et al. 2016; Amulen et al. 2017; Valdovinos-Flores et al. 2017).

\section{Colony collapse disorder}

This problem has occurred worldwide, and it needs management is the priority to save pollinator insects. With regard to the ecological and economic value of pollinators, there is a call to take an instantaneous action to spot and rectify anthropogenic activities responsible for the decline in numbers of pollinators to uphold crop production and environmental conservation. Colony collapse disorder was caused by different factors; neonicotinoids insecticides and pesticides exposure is one among the factors for the occurrence (Cox-Foster et al. 2007; Blanchard et al. 2008; Higes et al. 2008; vanEngelsdorp et al. 2009; Alaux et al. 2010; Henry et al. 2012; Krupke et al. 2012; Whitehorn et al. 2012).

\section{Use of pesticide to agricultural crops}

The application of pesticides is increasing in less developed countries to maximize crop production (Atreya 2007) and dramatically in Ethiopia (Nigatu et al. 2016). Research indicates that producers used pesticides for different purposes including for weed control, insect pest control, fungi/molds/rust control, rodent control, and veterinary uses (Kalayou and Amare 2015). In the agriculture sector pesticides have played a vital role in increasing crop production and without pesticide applications, crops would produce significantly lower yields due to factors insect damage, weed infestations and plant diseases (Ortelli et al. 2006). But considering its positive impact in agricultural crop production, the use of pesticides still have negative impacts on pollinators and other non-target organisms. Recent agricultural growth and development in Ethiopia resulted in higher demand and the use of pesticides.

Formally, government extension programs encourage the use of pesticides, arguing that farmers have no alternative for its application as an extension package (MoA 2013; Mengistie et al. 2014; Damte and Tabor 2015). Pesticide use designs of smallholder farmers are more complicated compared with large-scale farmers, as they are usually resource-poor as well as risk-averse. A report indicates that due to high exposure and unsafe application techniques of pesticide, smallholders experience more pesticide health risks than larger-scale farmers (Ngowi et al. 2007; Williamson et al. 2008). Application of pesticide requires training; apply safety rules, proper time and techniques for both the farmers and habitat around include the more sensitive honeybees.

\section{The types using of pesticides}

Various types of pesticides, insecticides, and herbicides were applied without consideration of the damage on honeybee colonies. The study indicates that except coffee and Enset (Ensete ventricosum) growers, those cereal and vegetable 
growers mainly used pesticides at a different level for production (Tilahun and Hussen 2014). It is estimated that about 541,4671 of pesticides are aerially sprayed at 514,923.6 ha of land to control crop pests in the regions of Ethiopia, with the highest beekeeping potential, namely Oromia, Amhara, and Tigray (Sintayehu and Tibebu 2016) Table 1.

\section{Pesticides using practices}

In Ethiopia, several shops are selling pesticides, and farmers have easy access to pesticides (Mengistie et al. 2017). Farmers use the improper storage of pesticides at home (Ajayi and Akinnifesi 2007; Ngowi et al. 2007). Some farmers mix two pesticides before application and this helps farmers to save their time, labor and they have considered it have higher efficacy in pests and diseases control (Kalayou and Amare 2015; Negatu et al. 2016; Mengistie et al. 2017). However, it is scientifically not recommended and does not label instructions to cover mixtures of two or more pesticides. Interactions between insecticides, fungicides and water mineral content may more toxic, risky, less efficient, neutralized or resistant of pesticides against fungal pathogens and insect mortality (Ngowi et al. 2007). Hence, an unspecified container of mixing of insecticide and fungicide are common practices with the vegetable farmers (Mengistie et al. 2017).

Farmers purchase pesticides without having proper knowledge, storing, safe handling, safe use, and disposing of. As a result, this may be hazardous to beneficial pollinators, including honeybees.

\section{Legislation and monitoring systems}

Policy plays a vital role in the implementation of any regulatory developed by the governments. Due to its importance and applicability Ethiopia has established policies and legal instruments towards production, use of pesticides, and also accepted and ratified different international conventions and agreements. Formally it developed in written form the constitution as proclamation No.1/1995, in which under article 43, in which it stated people's right to a clean and healthy environment and proper compensation provisions (FDRE 1995). In addition to this, the environmental policy of Ethiopia was also illustrated that prevention of pollution while sector environmental policies relating to soil husbandry and sustainable

Table 1 Pesticides types used in Ethiopia

\begin{tabular}{|c|c|c|}
\hline Type according to priority & References & Place were they apply \\
\hline DDT (55.2\%), Malathion (44.8\%) and 2-4 D (21.6\%) & $\begin{array}{l}\text { Tilahun and } \\
\text { Hussen } \\
\text { (2014) }\end{array}$ & Gedeo and Borena Zones, Ethiopia \\
\hline 2-4-D (97\%), Malathion (76\%) Actalic (methyl parathion) (24\%) & $\begin{array}{l}\text { Mengistu and } \\
\text { Beyene } \\
(2014)\end{array}$ & Gojjam Zone, Ethiopia \\
\hline $\begin{array}{l}\text { Malathion 50\%, phenetratite 50\% Ethiothoate } 40 \% \text {, Agrothoate } 40 \% \text {, } \\
\text { Diazion60\% EC, Dimethoate } 40 \% \text { EC, Ethiolathion 50\% EC or Malathion, } \\
\text { Karate 5EC, and herbicides like 2,4-D Amine, Zura, Diazion60\% EC, Agro- } \\
\text { Thoate } 40 \% \text {, Etho-Thoate } 40 \% \text {, Hepta clore, Phenetratite } 50 \% \text {, Daconil, } \\
\text { Diasnol, Primagram, Roundup, Agroset, Glycell and Terminator }\end{array}$ & $\begin{array}{r}\text { Desalegn } \\
(2014)\end{array}$ & Selected Districts of Amhara Region, Ethiopia \\
\hline $\begin{array}{l}\text { Chlorpyrifos dissolving in water, mixed Chlorpyrifos and Malathion, } \\
\text { Malathion, mixed Chlorpyrifos and } 24 \mathrm{D} \text { and 2,4 D alone }\end{array}$ & Shemsu (2016) & Bule Hora District, Ethiopia \\
\hline $\begin{array}{l}\text { Profenofos, Endosulfan, Diazinon, Malathion, Lambda-cyhalothrin, } \\
\text { Deltamethrin, Dimethoate and DDT }\end{array}$ & $\begin{array}{l}\text { Melisie et al. } \\
\quad(2016)\end{array}$ & Adami Tullu district of Ethiopia \\
\hline $\begin{array}{l}\text { Aldrin, } \alpha \text {-BHC, } \beta \text {-BHC, } \gamma \text {-BHC, Lindane, } \alpha \text {-chlorodan, } \gamma \text { - hlorodan, } \\
\text { 4,4'DDD, 4,4'DDE, 4,4'DDT, Dieldrine, } \alpha \text { - Endosulfan, } \beta \text {-Endosulfan, } \\
\text { Endosulfan sulfate, Endrine, Endrine } \\
\text { Aldehyde, Endrine Ketone, Heptachlor, Heptachlor Exo-epoxide, and } \\
\text { Methoxychlor. } \\
\text { Agro- } 2,4-D \text { amine } 720 \text { g/l A.E, Malathione (Ethiolation } 50 \% \text { EC), Karate } \\
\text { (Karate } 5 \% \text { EC), Dimothoate (Ethiothoate 40\%EC), Ridomil, Mancozeb, } \\
\text { Dursban (Dursban } 48 \% \text { EC),Fenithrothion (Ethiotrothion } 50 \% \text { EC), and } \\
\text { Diazinon (Ethiozinon } 60 \% \text { Ec. }\end{array}$ & $\begin{array}{c}\text { Eyobel et al. } \\
\text { (2017) } \\
\text { Guesh et al. } \\
(2018)\end{array}$ & $\begin{array}{l}\text { West Shewa Zone, Oromia Region, Ethiopia Selectec } \\
\text { zones of Tigray Region, Northern Ethiopia }\end{array}$ \\
\hline $\begin{array}{l}\text { Thiamethoxam, Imidacloprid, Deltamethrin, Abamectin, Spinosad Fosetyl } \\
\text { Aluminium, Boscalid, Metalaxyl, Chlorothalonil, Carbendazim, } \\
\text { Propamocarb, Hydrochloride, Iprodione, Profenofos, Mancozeb, } \\
\text { Lambdacyhalthrin, Endosulfan, Dimethoate, DDT, Metalaxyl, Chlorpyrifos, } \\
\text { Triadimefon, Mancozeb +Metalaxyl, and Cymoxanil } \\
\text { +Copperoxichloride }\end{array}$ & $\begin{array}{l}\text { Negatu et al. } \\
\text { (2016) }\end{array}$ & $\begin{array}{l}\text { In selected large scale (closed greenhouses and open } \\
\text { farms) and small-scale irrigated farms, Ethiopia }\end{array}$ \\
\hline
\end{tabular}


agriculture emphasize on the use of biological and cultural pest control approaches and safeguarding of environmental health by adequately regulating agricultural chemicals in the country (Ethiopian-EPA 1997).

Currently, the country was developed proclamation which is Pesticide Registration and Control Proclamation No. 674/ 2010 with the aim of laying down a scheme of control that would minimize the adverse effects that pesticide use might cause to humans, animals, and the environment. It also composes the need to enact comprehensive legislation to regulate the manufacture, formulation, import, export storage, distribution sale, use and disposal of pesticides (FDRE 2010). But, it is understandable that only designing the policy possibly addresses pesticide problems and accomplishes the objectives unless the participants along the chain are enforceable (FAO 2003; Brodesser et al. 2006; Mengistie 2016a, 2016b). In Ethiopia, the role played by the actors in pesticide governance is weak, enforcement all level along the production includes at the federal, regional and grass-root or district level is fundamental and the formulation of pesticide policy by the state is not sufficient by itself unless it is enforceable (Mengistie 2016a, 2016b). Enforcement of realistic pesticide policy is the most important component of monitoring the invaluable tool for verification of the conditions of exposure and the occurrence of risk in the field. Even if there are legislation (European Union) and proclamations (Ethiopia), but there is no official guide for performing monitoring studies for honeybees or other insect pollinators and monitoring studies were recommended (Alix and Garrido 2015; Mengistie et al. 2017).

\section{Mitigation schemes for the impact of pesticides on honeybee}

The majority of beekeepers do not use any control measures for chemical poisoning to honeybees (Mengistu and Beyene 2014). The application of pesticides was also affecting honeybee production by decreasing the number of workers bee through poisoning and is considered a conflict between beekeepers and crop producers. To minimize the risk of honeybee poisonings or unacceptable weakening of a colony, the registration procedures of plant protection products (PPPs) take this issue into account and integrated agricultural crop production with apiculture is critical. Only a few farmers protected their honeybees colonies from insecticide poisoning either by keeping beehives far away from the insecticide sprayed area or by closing the entrance of the hive and giving supplementary feeds during spraying (Melisie et al. 2016). Even if it is difficult to completely prevent the effect of chemicals on honeybees, their effect can be reduce by strengthening integrated pest management programs, using insecticides of relatively low toxicity and residual effect for bees and other pollinating insects, not applying insecticides toxic to bees when crops are flowering, use proper methods application (Askale et al. 2017). Another scientific report also suggested that beekeepers and crop producers should be aware of the location of honeybee hive before the pesticide application (Cardoza et al. 2012; Tomé et al. 2012; Williamson and Wright 2013), Positive communication between beekeepers and crop growers during spraying time (Guesh et al. 2018). Under Ethiopia's agricultural situation to minimize the risk of pesticide use, there is a need for timely advice and use of educational programs to beneficiaries, chemical applicators, and beekeepers on how to reduce poisoning by proper selection and application in insecticides. In addition to this, it is also important to avoid spraying pesticides to agricultural crops during the blooming stage. Beekeeping management techniques (like moving bees out of hazardous areas, supplementary feeding and various protective measures) that will reduce the harmful effect of exposure to insecticides should be developed and practiced (Kerealem et al. 2009).

Honeybees' pollination plays an essential role to improve yields and better quality of different crops (Berenbaum 2007; Klein et al. 2007; Winfree et al. 2007; Rader et al. 2009; Devkota et al. 2016). Because of the essential ecological and economic value of honeybees, there is a need to monitor and maintain pesticides application. And also to make the beekeeping sector sustainable, it is better to have an agreement between the crop producer and beekeepers on the implementation of those agrochemicals and use integrated pest management. The government should also be focused on formulating appropriate policies on the proper use of agrochemicals and accountability regarding the application (Kerealem et al. 2009).

\section{Perception of farmers on the impact of pesticides on honeybees}

The issue of knowledge, attitudes, and practices about pesticide usage and related health problems among irrigation farmers in Ethiopia has been left neglected (Gesesew et al. 2016). Majority of farmers use pesticides without full understanding of the impact on human health, honeybees and the environment (Matthews 2008; Melisie et al. 2016; Sintayehu and Tibebu 2016), farmers have having lack of appropriate knowledge on safe handling and use of pesticides (Ngowi 2003; Ibitayo 2006; Ngowi et al. 2007; Tilahun and Hussen 2014), use inappropriate practices (Mekonnen and Agonafir 2002), farmers are not fully aware of the amount of agrochemical recommended (Mengistu and Beyene 2014). The majority of farmers were not receiving pesticide-related training (Negatu et al. 2016). In another case around $63.2 \%$ of farmers usually followed the instructions/labels written on the containers of the pesticides (Gesesew et al. 2016). Farmers can use the pesticides effectively if they have the required knowledge, skill and experience (Brodesser et al. 2006; FAO 2008). 


\section{Time of pesticides use}

The study indicates that all of the farmers apply agrochemicals on barley, wheat, millet, and onion before blooming (Mengistu and Beyene 2014). In addition to this, the majority of the respondents apply the chemicals on mango $(92.9 \%)$, orange $(97.2 \%)$, potato $(81 \%)$ and maize $(81 \%)$ at blooming and liquid spray at the morning and at the middle of the day (Desalegn 2014; Mengistu and Beyene 2014; Melisie et al. 2016; Guesh et al. 2018). This man that they at the time when the honeybees were more visited time the flowering plants to collect nectar and pollen, as a result, they poison themselves or contaminate all the resources found the hive. Even if the majority of farmers apply pesticides ones per agricultural crop growing season but some farmers use twice and three times. On the other hand, according to Shemsu (2016), an assessment conducted in Bule Hora Districts of Ethiopia majority of farmers use pesticides four times per year. It's possible to conclude that as the frequency of pesticide application is increasing its impact including honey yield minimization, killing flowering plants, pollination service, population, absconding, forging behavior and others will be increasing. As a result, it may bring social conflict among farmers, economic and even ecological impact.

\section{Trends of pesticide use}

The trend of chemical utilization, including usage by smallholders, has been increasing (Ngowi et al. 2007; Gizachew 2011; Mengistu and Beyene 2014; Mengistie 2016a, 2016b). This is due to the expansion of agriculture packages to increase plant productivity nation-wide and accessibility of the various pesticides in a market. According to MoA (2011), indicates that 2973 metric tonne of pesticides in between 1996 and 1998, 3670 metric tonnes between 1999 and 2001, 5079 metric tonne between 2002 and 2004, 8302 metric tonne between 2005 and 2006 and in between 2006 and 2011 in which a total of $27,268.73$ metric tonnes of pesticide were imported to Ethiopia. But this data is only including the pesticides imported legally this is because of pesticide importing process into Ethiopia is not well-controlled (Mengistie 2016a, 2016b). In recent years, population increase led to a rise in demand for crops and cereals that increased with price incentives.

\section{Conclusions}

Honey bees (Apis mellifera L.) play an important ecological and economic role in the pollination service of crops. But recent global declining on pollinators, including honeybees' has reported owing to several factors includes unwise use and practice of pesticides.

Both beekeepers and non-beekeepers farmers buying, storing, and use pesticides on cultivated crops with no or little consideration on the effect of honeybees. The use of pesticides was affecting the bees directly through poisoning, death, flight, behavior, communication, and indirectly through destroying the honeybees' forage; it results in poor quality and quantity of hive products. Use of pesticides affected both to the honeybee colonies and beekeepers, and the contaminating of hive products absconding the honeybees and creates socio-economic conflict among community members.

Farmers used pesticides during the flower or blooming stage, and this is at a time which field bee actively collected nectar and pollen; as a result, it damages the bees. Farmers used pesticides for different purposes with no or little consideration on its impact on the environment, pollinators including honeybees. Farmers also apply pesticides up to four times per production session; the frequency of use also increases its impact on the honeybees. Considering saving their time, labor and its higher efficacy farmers practice mixing of two pesticides before the application and which is scientifically illegal and adheres to substantial risk on honeybees and beekeepers also. Following the need to improve agricultural crop production, the lack and use of pesticides application are having been increased from time to time.

Honeybee productivity is affected by the indiscriminate use of agrochemicals, lack of knowledge, pests and predators accordingly. It needs urgent action from the federal and regional governments to formulate policy, design legislation, and enforcing for its implementation concerning the supply, transportation, storage, appropriateness, and application of harmful pesticides.

Research should focus on the effects of pesticide use on honeybees and means of minimizing their results as well as on the development of non-chemical methods of insect control is very vital. In order to make the apiculture sector is sustainable, it is better to create an agreement between the crop producer and beekeepers on the use of the insecticide and use integrated pest management, covering or moving the hive to the poising free area, follow proper application practice is very vital. The regional governments should provide insecticide-open sanctuaries and crop zones where bees can be isolated from insecticides' effect. The government should also be focused on formulating appropriate policies on the proper use of pesticides and monitoring its implementation.

Acknowledgments First, I would like to express my heart full gratitude to my friends Mr. Gedam Brhane and Dr. Tesfay Hailu for providing critical comments and suggestions besides spending lots of their valuable time editing this manuscript. Lastly, I would like to express my heartfelt acknowledgment to my family for their care and encouragement. 


\section{Compliance with ethical standards}

Conflicts interests The author declares that there is no conflict of interest.

Ethics approval and consent to participate Not applicable.

Consent for publication Not applicable.

Abbreviations AAAA, American Association for the Advancement of Science; CADU, Chilalo Agricultural Development Unit; EPA, Environmental Protection Authority; EPID, Extension and Project Implementation Department; FAO, Food and Agriculture Organization of the United Nations; FDRE, Federal Democratic Republic of Ethiopia; MoA, Ministry of Agriculture; MPP, Minimum Package Project; MOWR, Ministry of Water Recourses; MRL, Maximum Residue Levels; WADU, Wolaita Agricultural Development Unit

Open Access This article is licensed under a Creative Commons Attribution 4.0 International License, which permits use, sharing, adaptation, distribution and reproduction in any medium or format, as long as you give appropriate credit to the original author(s) and the source, provide a link to the Creative Commons licence, and indicate if changes were made. The images or other third party material in this article are included in the article's Creative Commons licence, unless indicated otherwise in a credit line to the material. If material is not included in the article's Creative Commons licence and your intended use is not permitted by statutory regulation or exceeds the permitted use, you will need to obtain permission directly from the copyright holder. To view a copy of this licence, visit http://creativecommons.org/licenses/by/4.0/.

\section{References}

AAAS (2013) Infographic: pesticide planet. Science 341:728-731

Ajayi OC (2005) Biological capital, user costs, and the productivity of insecticides in cotton farming systems in sub-Saharan Africa. Int J Agric Sustain 3:154-166

Ajayi O, Akinnifesi F (2007) Farmers' understanding of pesticide safety labels and field spraying practices: a case study of cotton farmers in northern Côte d'Ivoire. Sci Res Essays 2:204-210

Alaux C, Brunet JL, Dussaubat C, Mondet F, Tchamitchan S, Cousin M, Brillard J, Baldy A, Belzunces LP, Le Conte Y (2010) Interactions between Nosema microspores and a neonicotinoid weaken honeybees (Apis mellifera). Environ Microbiol 12:774-782

Alburaki M, Steckel JS, Williams TM, Skinner AJ, Tarpy RD, William G, Meikle GM, Adamczyk J, Stewart DS (2017) Agricultural landscape and pesticide effects on honey bee (Hymenoptera: Apidae) biological traits. J Econ Entomol 0: 1-13

Alebachew WG (2018) Economic value of pollination service of agricultural crops in Ethiopia: biological pollinators. J Apic Sci 62:265273

Alix A, Garrido C (2015) Monitoring effects of pesticides on pollinators a review of methods and outcomes by the ICPPR working group. Julius- Kühn-Archiv 450:284-295

Allsopp MH, De Lange WJ, Veldtman R (2008) Valuing insect pollination services with cost of replacement. PLoS One 3:e3128

Allsopp M, Tirado R, Johnston P, Santillo D, Lemmens P (2014) Plan bee living without pesticides. Moving towards ecological farming, Greenpeace International
Amssalu B, Nuru A, Radloff E, Hepburn R (2004) Multivariate morphometric analysis of honeybees (Apis mellifera) in the Ethiopian region. Apidologie 35:71-81

Amulen DR, Spanoghe P, Houbraken M, Tamale A, Graaf DC, Cross P, Smaggh G (2017) Environmental contaminants of honeybee products in Uganda detected using LC-MS/MS and GC-ECD. PLoS One 12:e178546

Askale A, Malede B, Yitayew D, Ayalew N (2017) Major constraints and mitigation schemes for declining honey bee population in Ethiopia. Nat Sci 15:27-33

Atreya K (2007) Pesticide use knowledge and practices: a gender differences in Nepal. Environ Res 104:305-311

Belzunces LP, Tchamitchian S, Brunet JL (2012) Neural effects of insecticides in the honey bee. Apidologie 43:348-370

Berenbaum MR (2007) The birds and the bees-how pollinators help maintain healthy ecosystems. Testimonial before the subcommittee on fisheries, wildlife and oceans, committee on natural resources, U.S. House of Representatives

Blanchard P, Schurr F, Celle O, Cougoule N, Drajnudel P, Thiéry R, Faucon JP, Ribière M (2008) First detection of Israeli acute paralysis virus (IAPV) in France, a dicistrovirus affecting honeybees (Apis mellifera). J Invertebr Pathol 99:348-350

Blasco C, Vazquez-Roig P, Onghena M, Masia A, Pico Y (2011) Analysis of insecticides in honey by liquid chromatography-ion trap-mass spectrometry: comparison of different extraction procedures. J Chromatogr A 1218:4892-4901

Bogdanov S, Haldimann M, Luginbühl W, Gallmann P (2007) Minerals in honey environmental, geographical and botanical aspects. J Apic Res Bee Cult 46:269-275

Bortolotti L, Mutinelli F, Lavazza A, Piro R (2009) Spring honey bee losses in Italy. Julius-Kühn-Archiv 423:148-152

Brandt A, Gorenflo A, Siede R, Meixner M, Buchler R (2016) The neonicotinoids thiacloprid, imidacloprid, and clothianidin affect the immunocompetence of honey bees (Apis mellifera L.). J Insect Physiol 86:40-47

Brodesser J, Byron DH, Cannavan A, Ferris IG, Gross-Helmert K, Hendrichs J, Maestroni BM, Unsworth J, Vaagt G, Zapata F (2006) Pesticides in developing countries and the international code of conduct on the distribution and the use of pesticides. FAO/IAEA Joint Programme, Consultant, FAO

Cardoza YJ, Harris GK, Grozinger CM (2012) Effects of soil quality enhancement on pollinator-plant interactions. Psyche J Entomol 18. https://doi.org/10.1155/2012/581458

Chakrabarti P, Rana S, Sarkar S, Smith B, Basu P (2015) Pesticide induced oxidative stress in laboratory and field populations of native honey bees along intensive agricultural landscapes in two eastern Indian states. Apidologie 46:107-129

Chauzat MP, Faucon JP, Martel AC, Lachaize J, Cougoule N, Aubert M (2006) A survey of pesticide residues in pollen loads collected by honey bees in France. J Econ Entomol 99:253-262

Claudianos C, Ranson H, Johnson RM, Biswas S, Schuler MA, Barenbaum MR, Oakeshott JG (2006) A deficit of detoxification enzymes: pesticide sensitivity and environmental response in the honeybee. Insect Mol Biol 15:615-636

Cox-Foster DL, Conlan S, Holmes EC, Palacios G, Evans JD, Moran NA, Quan PL, Briese T, Hornig M, Geiser DM, Martinson V, vanEngelsdorp D, Kalkstein AL, Drysdale A, Hui J, Zhai J, Cui L, Hutchison SK, Simons JF, Egholm M, Pettis JS, Lipkin WI (2007) A metagenomic survey of microbes in honey bee colony collapse disorder. Science 318:283-287

Damte T, Tabor G (2015) Small-scale vegetable producers' perception of pests and pesticide uses in east Shewa zone. Ethiop Int J Pest Manag $61: 1-8$

Desalegn B (2014) Assessment of pesticides use and its economic impact on the apiculture subsector in selected districts of Amhara region, Ethiopia. J Environ Anal Toxicol 5:1-4 
Desneux N, Decourtye A, Delpuech JM (2007) The sublethal effects of pesticides on beneficial arthropods. Annu Rev Entomol 52:81-106

Devkota K, Dhakal CS, Thapa BR (2016) Economics of beekeeping as pollination management practices adopted by farmers in Chitwan district of Nepal. Agric Food Secur 5:1-6

Di Prisco G, Cavaliere V, Annoscia D, Varricchio P, Caprio E, Nazzi F, Gargiulo G, Pennacchio F (2013) Neonicotinoid clothianidin adversely affects insect immunity and promotes replication of a viral pathogen in honey bees. Proc Natl Acad Sci U S A 110:18466-18471

Eiri DM, Nieh JC (2012) A nicotinic acetylcholine receptor agonist affects honey bee sucrose responsiveness and decreases waggle dancing. J Exp Biol 215:2022-2029

Eissa F, El-Sawi S, Zidan NE (2014) Determining pesticide residues in honey and their potential risk to consumers. Pol J Environ Stud 23: $1573-1580$

EPA (2004) Environmental Impact Assessment Guideline on Pesticides, Addis Ababa, Ethiopia

Erik S (2013) Pesticides under fire for risks to pollinators. Science 340: 674-676

Ethiopian-EPA (1997) Environmental Policy of Ethiopia Addis Ababa: Environmental Protection Authority

Eyobel M, Wodaje A, Lemessa B, Miresa T (2017) Physicochemical characterization and pesticide residue analysis of honey produced in west Shewa zone, Oromia region, Ethiopia. Am J Appl Chem 5: $101-109$

FAO (2003) International code of conduct on the distribution and use of pesticides. Food and Agriculture Organization of the United Nations, Rome

FAO (2008) Key messages from a study on Ethiopia's extension systems. Addis Ababa, FAO Sub Regional Office for Eastern Africa and FAO Representation in Ethiopia

FDRE (1995) In: Government E (ed) Proclamation of the Ethiopian constitution no. 1/95. Federal Negarit Gazeta, Addis Ababa

FDRE (2010) In: Government TE (ed) Pesticide registration and control proclamation no.674/2010. Federal Negarit Gazeta, Addis Ababa

Feltham H, Park K, Goulson D (2014) Field realistic doses of pesticide imidacloprid reduces bumblebee pollen foraging efficiency. Ecotoxicology 23:317-323

Fischer J, Muller T, Spatz AK, Greggers U, Grunewald B, Menzel R (2014) Neonicotinoids interfere with specific components of navigation in honeybees. PLoS One 9:e91364

Frazier M, Mullin C, Frazier J, Ashcraft S (2008) What havepesticides got to do with it? Am Bee J 148:521-523

Gesesew HA, Woldemichael K, Massa D, Mwanri L (2016) Farmers knowledge, attitudes, practices and health problems associated with pesticide use in rural irrigation villages, Southwest Ethiopia. PLoS One 11:e0162527

Gill RJ, Ramos-Rodriguez O, Raine NE (2012) Combined pesticide exposure severely affects individual-and colony-level traits in bees. Nature 491:105-108

Gizachew A (2011) Pesticide use in Ethiopia. Ministry of Agriculture Addis Ababa

Guesh G, Amssalu B, Hailu M, Yayneshet T (2018) Beekeeping management practices and gap analysis of beekeepers at different agroecological zones of Tigray region, northern Ethiopia. J Agric Ext Rural Dev 10:260-271

Gysen J, Bruyninckx H, Bachus K (2006) The modus Narrandi: a methodology for evaluating effects of environmental policy. SAGE Publ 12:95-118

Henry M, Béguin M, Requier F, Rollin O, Odoux JF, Aupinel P, Aptel J, Tchamitchian S, Decourtye A (2012) A common pesticide decreases foraging success and survival in honey bees. Science 336:348-350

Higes M, Martin-Hernandez R, Botlas C, Bailon EG, Gonzalez-Porto AV, Barrios L, Del Nozal MJ, Bernal JL, Jiménez JJ, Palencia PG, Meana A (2008) How natural infection by Nosema ceranae causes honeybee colony collapse. Environ Microbiol 10:2659-2669
Ibitayo OO (2006) Egyptian farmers' attitudes and behaviors regarding agricultural pesticides: implications for pesticide risk communication. Risk Anal 26:989-995

Johnson RM, Ellis MD, Mullin CA, Frazier M (2010) Pesticides and honey bee toxicity - USA. Apidologie 41:312-331

Kalayou HG, Amare AA (2015) Assessment of pesticide use, practice and environmental effects on the small holder farmers in the north Shoa zone of Amhara national regional state of Ethiopia. Res J Agric Environ Sci 2:16-24

Kebebe D (2019) Study on pesticide residues and heavy metals levels in honey samples collected from Walmara District of Oromia special zone, Ethiopia. Sci J Food Sci Nutri 5:1-5

Kerealem E, Tilahun G, Preston TR (2009) Constraints and prospects for apiculture research and development in Amhara region, Ethiopia. Livest Res Rural Dev 21:172

Klein AM, Vaissière BE, Cane JH, Steffan DI, Cunningham SA, Kremen C, Tscharntke T (2007) Importance of pollinators in changing landscapes for world crops. Proc R Soc B 274:303-313

Krupke CH, Hunt GJ, Eitzer BD, Andino G, Given K (2012) Multiple routes of pesticide exposure for honey bees living near agricultural fields. PLoS One 7:e29268

Krystyna P, Teresa S, Monika W, Artur M, Piotr S (2017) The exposure of honey bees to pesticide residues in the hive environment with regard to winter colony losses. J Apic Sci 61:105-125

Le Conte Y, Navajas M (2008) Climate change: impact on honey bee populations and diseases. Rev Sci Tech Int Off Epizootics 27:499 510

Lebuhn G, Droege S, Connor EF, Gemmill-Herren B, Potts SG, Minckley RL, Griswold T, Jean R, Kula E, Roubik DW, Cane J, Wright KW, Frankie G, Parker F (2013) Detecting insect pollinator declines on regional and global scales. Conserv Biol 27:113-120

Maini S, Medrzycki P, Porrini C (2010) The puzzle of honey bee losses: a brief review. Bull Insectol 63:153-160

Martel AC, Zeggane S, Auriéres C, Drajnudel P, Faucon JP, Aubert M (2007) Acaricide residues in honey and wax after treatment of honey bee colonies with Apivar ${ }^{\circledR}$ or Asuntol® 50. Apidologie 38:534-544

Matthews GA (2008) Attitudes and behaviors regarding use of crop protection products- a survey of more than 8500 smallholders in 26 countries. Crop Prot 27:834-846

Mekonnen Y, Agonafir T (2002) Pesticide sprayers' knowledge, attitude and practice of pesticide use on agricultural farms of Ethiopia. Occup Med 52:311-315

Melaku G, Shifa B, Azage T, Negatu A, Lulseged B (2008) Approaches, methods and processes for innovative apiculture development: Experiences from Ada'a-Liben Woreda, Oromia Regional State, Ethiopia. IPMS of Ethiopian Farmers Project Working Paper 8, ILRI (International Livestock Research Institute), Nairobi, Kenya

Melisie M, Tebkew DT, Thakur KA (2015) Effect of some insecticidal chemicals under laboratory condition on honey bees [Apismellifera L. (hymenoptera: Apidae)] that forage on onion flowers. Afr J Agric Res 10:1295-1300

Melisie M, Tebkew DT, Thakur KA (2016) Farmers' insecticide use practice and its effect on honeybees (Apis mellifera) foraging on onion flower in Adami Tullu district of Ethiopia. Glob J Pests Dis Crop Prot 4:139-145

Mengistie BT (2016a) Environmental governance of pesticides in Ethiopian vegetable and cut flower production. $\mathrm{PhD}$ thesis, Wageningen University, Wageningen

Mengistie BT (2016b) Policy-practice Nexus: pesticide registration, distribution and use in Ethiopia. SM J Environ Toxicol 2:1-13

Mengistie BT, Mol APJ, Oosterveer P, Simane B (2014) Information, motivation and resources: the missing elements in agricultural pesticide policy implementation in Ethiopia. Int J Agric Sustain 13:240-256

Mengistie BT, Mol APJ, Oosterveer P (2017) Pesticide use practices among smallholder vegetable farmers in Ethiopian central Rift Valley. Environ Dev Sustain 19:301-324 
Mengistu ZM, Beyene JT (2014) Beekeeping in Ethiopia, a case of agrochemical uses in west Gojjam zone. Bee World 91:8-11

MoA (2011) Post registration activities and challenges in pesticide: presentation on stakeholders meeting organized by PRRP and APHRD of the MOA, Addis Ababa, Ethiopia

MoA (2013) National Pesticide Management Strategies in Ethiopia, APHRD of MoA, Unpublished Official Reports

MOWR (2007) Awash River basin flood control and watershed management study project, phase -2 summery report, Annex-B, Addis Abeba, Ethiopia

Muli E, Patch H, Frazier M, Frazier J, Torto B (2014) Evaluation of the distribution and impacts of parasites, pathogens, and pesticides on honey bee (Apis mellifera) populations in East Africa. PLoS One 9:e94459

Mullin CA, Frazier M, Frazier JL, Ashcraft S, Simonds R, vanEngelsdorp D, Pettis JS (2010) High levels of miticides and agrochemicals in north American apiaries: implications for honey bee health. PLoS One 5:e9754

Nakasu EYT, Williamson SM, Edwards MG, Fitches EC, Gatehouse JA, Wright GA, Gatehouse AM (2014) Novel biopesticide based on a spider venom peptide shows no adverse effects on honeybees. Proc R Soc B 281:1-9

Negatu B, Kromhout H, Mekonnen Y, Vermeulen R (2016) A Crosssectional comparative study on knowledge, attitude and practice of farmers and farm workers in three farming systems. Ann Occup Hyg 60:551-566

Ngowi AVF (2003) A study of farmers' knowledge, attitude and experience in the use of pesticides in coffee farming. Afr Newsl Occup Health Safety 13:62-64

Ngowi AVF, Mbise TJ, Ijani ASM, London L, Ajayi OC (2007) Smallholder vegetable farmers in northern Tanzania: pesticides use practices, perceptions, and cost and health effects. Crop Prot 26:1617-1624

Nigatu AW, Bråtveit M, Moen BE (2016) Self-reported acute pesticide intoxications in Ethiopia. BMC Public Health 16:1-8

Ortelli D, Edder P, Corvi C (2006) Multiresidue analysis of 74 pesticides in fruits and vegetables by liquid chromatography-electrospray-tandem mass spectrometry. Anal Chim Acta 520:33-45

Ostiguy N, Eitzer B (2014) Overwintered brood comb honey: Colony exposure to pesticide residues. J Apic Res 53:413-421

Pistorius J, Bischoff G, Heimbach U (2009) Bee poisoning by abrasion of active substances from seed treatment of maize during seeding in spring 2008. J Kult 61:9-14

Pistorius J, Wehner A, Kriszan M, Bargen H, Knäbe S, Klein O, Heimbach U (2015) Application of predefined doses of neonicotinoid containing dusts in field trials and acute effects on honey bees. Bull Insectol 68:161-172

Porrini C, Sabatini AG, Girotti S, Ghini S, Medrzycki P, Grillenzoni F, Bortolotti L, Gattavecchia E, Celli G (2003) Honey bees and bee products as monitors of the environmental contamination. Apiacta 38:63-70

Porrini C, Mutinelli F, Bortolotti L, Granato A, Laurenson L, Roberts K, Gallina A, Silvester N, Medrzycki P, Renzi T, Sgolastra F, Lodesani M (2016) The status of honey bee health in Italy: results from the Nationwide bee monitoring network. PLoS One 11:e0155411

Potts SG, Biesmeijer JC, Kremen C, Neumann P, Schweiger O, Kunin WE (2010) Global pollinator declines: trends, impacts and drivers. Trends Ecol Evol 25:345-353

Rader R, Howlett BG, Cunningham SA, Westcott DA, Newstrom-Lloyd LE, Walker MK, Teulon DA, Edwards W (2009) Alternative pollinator taxa are equally efficient but not as effective as the honeybee in a mass flowering crop. J Appl Ecol 46:1080-1087

Roubik DW, Sihag RC, Kevan PG, Garibaldi LA, Cunningham SA (2018) The pollination of cultivated plants: a compendium for practitioners. Food and Agriculture Organization of the United Nations (FAO), Balboa

Said F, Inayatullah M, Ahmad S, Iqbal T, Shah R (2015) A foraging behavior of the Himalayan honeybee, Apis cerana (Hymenoptera: Apidae) associated with sunflower (Helianthus annuus L.) at
Peshawar District of Khyber Pakhtunkhwa (KP). J Entomol Zool Stud 3:203-207

Schneider CW, Tautz J, Grünewald B, Fuchs S (2012) RFID tracking of sublethal effects of two neonicotinoid insecticides on the foraging behavior of Apis mellifera. PLoS One 7:e30023

Shemsu L (2016) Assessments of pesticide use and practice in Bule Hora districts of Ethiopia. Haya Saudi J Life Sci 1:103-108

Simon-Delso N, Martin GS, Bruneau E, Minsart LA, Mouret C (2014) Honeybee colony disorder in crop areas: the role of pesticides and viruses. PLoS One 9:e103073

Sintayehu F, Tibebu H (2016) Effects of herbicide application in wheat crops and on honeybee populations in Ethiopia, the U.S. governments Global Hunger \& Food Security initiatives, feed the futureresearch report

Stanley DA, Garratt MPD, Wickens JB, Wickens JB, Potts SG, Raine NE (2015) Neonicotinoid pesticide exposure impairs crop pollination services provided by bumblebees. Nature 528:548-550

Tadesse AS (2016) Stewardship towards responsible management of pesticides, the case of Ethiopian agriculture. Doctoral thesis Swedish University of agricultural, sciences pp 87

Tadesse A, Asferachew A (2008) An assessment of the pesticide use, practice and hazards in the Ethiopian rift valley, Africa Stockpiles Programme

Tilahun B, Hussen A (2014) Assessment of pesticide use, practice and risk in Gedeo and Borena zones; Ethiopia. Int J Environ 3:201-209

Tomé HVV, Martins GF, Lima MAP, Campos LAO, Guedes RNC (2012) Imidacloprid-induced impairment of mushroom bodies and behavior of the native stingless bee. PLoS One 7:e38406

Valdovinos-Flores C, Alcantar-Rosales MV, Gaspar-Ramírez O, SaldañaLoza ML, Dorantes-Ugalde AJ (2017) Agricultural pesticide residues in honey and wax combs from southeastern, central and northeastern Mexico. J Apic Res 56:667-679

Van der Sluijs JP, Simon-Delso N, Goulson D, Maxim L, Bonmatin JM, Belzunces LP (2013) Neonicotinoids, bee disorders and the sustainability of pollinator services. Curr Opin Environ Sustain 5:293-305

vanEngelsdorp D, Meixner MD (2010) A historical review of managed honey bee populations in Europe and the United States and the factors that may affect them. J Invertebr Pathol 103:80-95

vanEngelsdorp D, Evans JD, Saegerman C, Mullin C, Haubruge E, Nguyen BK, Frazier M, Frazier J, Cox-Foster D, Chen Y, Underwood R, Tarpy DR, Pettis JS (2009) Colony collapse disorder: a descriptive study. PLoS One 4:e6481

Whitehorn PR, O'Connor S, Wackers FL, Goulson D (2012) Neonicotinoid pesticide reduces bumble bee colony growth and queen production. Science 336:351-352

Wiest L, Bulete A, Giroud B, Fratta C, Amic S (2011) Multi-residue analysis of 80 environmental contaminants in honeys, honey bees and pollens by one extraction procedure followed by liquid and gas chromatography coupled with mass spectrometric detection. J Chromatogr A 1218:5743-5756

Williamson SM, Wright GA (2013) Exposure to multiple cholinergic pesticides impairs olfactory learning and memory in honeybees. J Exp Biol 216:1799-1807

Williamson S, Ball A, Pretty J (2008) Trends in pesticide use and drivers for safer pest management in four African countries. Crop Prot 27: $1327-1334$

Williamson SM, Willis SJ, Wright GA (2014) Exposure to neonicotinoids influences the motor function of adult worker honeybees. Ecotoxicology 23:1409-1418

Winfree R, Williams NM, Dushoff J, Kremen C (2007) Native bees provide insurance against ongoing honey bee losses. Ecol Lett 10: $1105-1113$

Publisher's note Springer Nature remains neutral with regard to jurisdictional claims in published maps and institutional affiliations. 